KINETIK, Vol.1, No.1, Mei 2016, Hal. 23-32

ISSN : 2503-2259,

E-ISSN : 2503-2267

\title{
Sistem Pengaturan Kecepatan Motor Induksi Tiga Fasa Menggunakan Kontroler PID Berbasis Genetic Algorithm
}

\author{
Fatih Mutammimul Wildan', Ermanu Azizul Hakim², Diding Suhardi ${ }^{3}$ \\ 1,2,3 Universitas Muhammadiyah Malang \\ fatihmutammimulwildan@gmail.com¹, ermanu.ahakim@gmail.com² ${ }^{2}$,didingsuhardi@umm.ac.id ${ }^{3}$
}

\begin{abstract}
Abstrak
Motor induksi tiga fasa merupakan peralatan penggerak yang paling banyak digunakan dalam dunia industri karena mempunyai konstuksi yang kuat dan sederhana. Dalam pengaturan kecepatan pada motor induksi tiga fasa diperlukan adanya inverter sebagai alat yang berfungsi untuk megatur kecepatan motor dengan mengubah nilai frekuensi. Untuk mengatur nilai frekuensi yang sesuai pada inverter dibutuhkan suatu krontroler, salah satu kontroler yang paling banyak digunakan adalah kontroler PID. Nilai parameter kontrol yang ada pada kontroler PID sangat berpengaruh terhadap respon kecepatan motor, sehingga diperlukan sebuah metode pencarian yang mana digunakan GA dalam penentuan parameter kontrol PID. Penentuan parameter kontrol PID menggunakan GA dilakukan dengan lima jangkauan pembatasan pada nilai pembangkitan individu sehingga didapatkan berbagai macam nilai yang berbeda-beda dan diharapkan sesuai dengan respon kecepatan yang diinginkan. Berdasarkan hasil pengujian yang telah dilakukan diketahui bahwa respon kecepatan motor setelah diberikan kontroler PID berbasis GA dapat mencapai kecepatan referensi $120 \mathrm{rad} / \mathrm{s}$ dengan kecepatan aktual saat beban $100 \mathrm{Nm}$ sebesar 120,1 rad/s sehingga didapatkan $e_{s s} 0,083 \%$.
\end{abstract}

Kata kunci: Motor induksi tiga fasa, Inverter, PID, Genetic Algorithm

Abstract
Three phase induction motor is a propulsion equipment most widely used in industry because it has a strong and simple construction purposes. In setting the pace in three phase induction motor inverter is needed as a tool that serves to regulate the speed of the motor by changing the frequency values. To set the value of the corresponding frequency inverter requires a controller, one of the most widely used controller is a controller PID. Control parameter values that exist in the PID controller affects the response speed of the motor, necessitating a search method which used GA in the determination of PID control parameters. Determination of PID control parameters using GA was done with five range of restrictions on the value of the generation of the individual to obtain a wide range of different values and expected according to the desired response speed. Based on results test that have been made known that the response speed of the motor after being given a PID controller based on GA can achieve the reference speed $120 \mathrm{rad} / \mathrm{s}$ with actual speed while load $100 \mathrm{Nm}$ in the amount of $120,1 \mathrm{rad} / \mathrm{s}$ than obtained $e_{s s} 0,083 \%$.

Keywords: Three phase induction motor, Inverter, PID, Genetic Algorithm

\section{Pendahuluan}

Motor induksi 3 fasa merupakan motor arus bolak-balik yang paling banyak digunakan sebagai aktuator yang merubah energi listrik menjadi energi gerak untuk berbagai keperluan dalam proses produksi pada suatu industri. Konstruksinya yang sederhana dan kuat mendasari alasan keluasan pemakaianya. Namun motor induksi 3 fasa tidak terlepas dari beberapa kekurangan seperti arus start yang besar dan nilai overshoot motor yang mempengaruhi performa motor induksi tersebut [1]-[5].

Sebagai pengendali motor induksi 3 fasa diperlukan adanya sebuah inverter. Inverter merupakan sebuah alat pengatur kecepatan motor dengan mengubah nilai frekuensi yang masuk ke motor. Pengaturan nilai frekuensi ini dimaksudkan untuk memperoleh kecepatan putaran yang di inginkan atau sesuai dengan kebutuhan. Namun dalam inverter itu sendiri perlu 
ditambahkan sebuah kontroler sehingga nilai kontrol terhadap motor dapat disesuaikan dengan kebutuhan yang diinginkan. PWM adalah salah satu teknik untuk mengatur penyaklaran transistor dalam inverter. Teknik ini pada dasarnya adalah membandingkan dua sinyal untuk mendapatkan pola penyaklaran transistor [6]-[9].

Kontroler Proporsional Integral Derivative (PID) merupakan sebuah pengontrol yang paling banyak digunakan dalam bidang sistem kontrol di dunia industri. Hal tersebut dikarenakan kontroler PID mempunyai tiga konstanta kontrol dimana ketiga konstanta tersebut mempunyai kelebihan dan kekurangan masing-masing. Tetapi dengan penggabungan ketiga kontanta tersebut secara paralel dapat menutupi setiap kekurangan dan kelebihan dari masingmasing konstanta sehingga didapatkan suatu kontroler yang baik. Namun dalam penentuan nilai konstanta PID diperlukan sebuah metode agar dapat dihasilkan sebuah kontroler yang baik. Untuk sistem kontrol linear, menentukan karakteristik dari tanggapan peralihan sering dilakukan menggunakan fungsi tangga satuan (unit-step) sebagai masukan. Tanggapan dari suatu sistem kontrol ketika masukan berupa fungsi tangga satuan disebut unit step response [11]-[13].

Terdapat beberapa batasan yang menjadi parameter algoritma. Jika dalam proses evolusi, banyaknya individu dalam suatu populasi tidak dibatasi, maka dalam GA hanya dibatasi dalam ukuran populasi. Kemungkinan suatu individu kawin dengan individu lainnya juga dijadikan sebagai parameter algoritma dan dikenal sebagai probabilitas penyilangan. Demikian juga dengan kemungkinan terjadinya mutasi pada suatu individu, yang dikenal sebagai probabilitas mutasi. Bahkan berlangsungnya proses komputasi juga dibatasi dalam Algoritma Genetika sampai suatu kondisi terpenuhi [14],[15].

MATLAB (Matrix Laboratory) adalah sebuah program untuk analisis dan komputasi numerik dan merupakan suatu bahasa pemrograman matematika lanjutan yang dibentuk dengan dasar pemikiran menggunkan sifat dan bentuk matriks. Penulisan barisan ekspresi dalam MATLAB command window biasanya dilakukan baris perbaris dan biasanya untuk menyimpan barisan perintah dan hasil outputnya dengan menggunakan command diary. Simulink adalah graphical extension MATLAB untuk memodelkan dan mensimulasikan sebuah system. Dalam Simulink, sistem digambarkan sebagai sebuah block diagram, diantaranya transfer function, summing junction, didalamnya terdapat pula virtual input dan output device seperti function generator dan oscilloscope. Sedangkan pada simulink, data/informasi dari berbagai block dikirim ke block lainnya dihubungkan dengan garis [10],[16],[17].

Berdasarkan latar belakang masalah yang telah di jabarkan tersebut maka penulis ingin mengembangkan sistem kontrol yang terdapat pada inverter terutama kontroler PID dengan menggunakan metode Genetic Algorithm (GA).

\section{Metode Penelitian}

Perancangan dan pemodelan sistem dilakukan untuk menunjukan kondisi kontrol kecepatan motor induksi tiga fasa pada inverter yang akan dikontrol menggunakan kontroler PID berbasis GA.

Pemodelan sistem pengontrolan kecepatan motor menggunakan inverter dengan kontroler PID berbasis GA seperti terlihat dalam Gambar 1. Dari sumber tegangan DC digunakan sebagai masukan pada inverter sehingga dapat diubah menjadi tegangan AC dengan penyesuaian frekuensi yang dapat diatur untuk memutar motor induksi tiga fasa. Kecepatan aktual dari motor induksi kemudian dibandingkan dengan kecepatan referensi, selisih dari perbandingan kecepatan motor tersebut diumpan balikkan ke kontroler PID.

Metode GA digunakan sebagai metode penentuan parameter kontroler $\mathrm{Kp}, \mathrm{Ki}$ dan $\mathrm{Kd}$ yang ada pada PID sehingga didapatkan pendekatan dengan nilai error yang kecil. Keluaran dari kontroler PID masuk ke dalam vector control, bersama dengan arus aktual (I abc aktual). Dari hasil vector control didapatkan arus referensi (I abc referensi), kemudian arus aktual dan arus referensi digunakan sebagai masukan pada hysteresist current control untuk menghasilkan pulsa. Pulsa ini digunakan sebagai pemicu untuk pengaturan penyalaan enam buah Insulated 
Gate Bipolar Transistor (IGBT) pada inverter. Pengaturan waktu dari proses penyalaan frekuensi yang digunakan untuk mengatur putaran motor induksi yang digunakan.

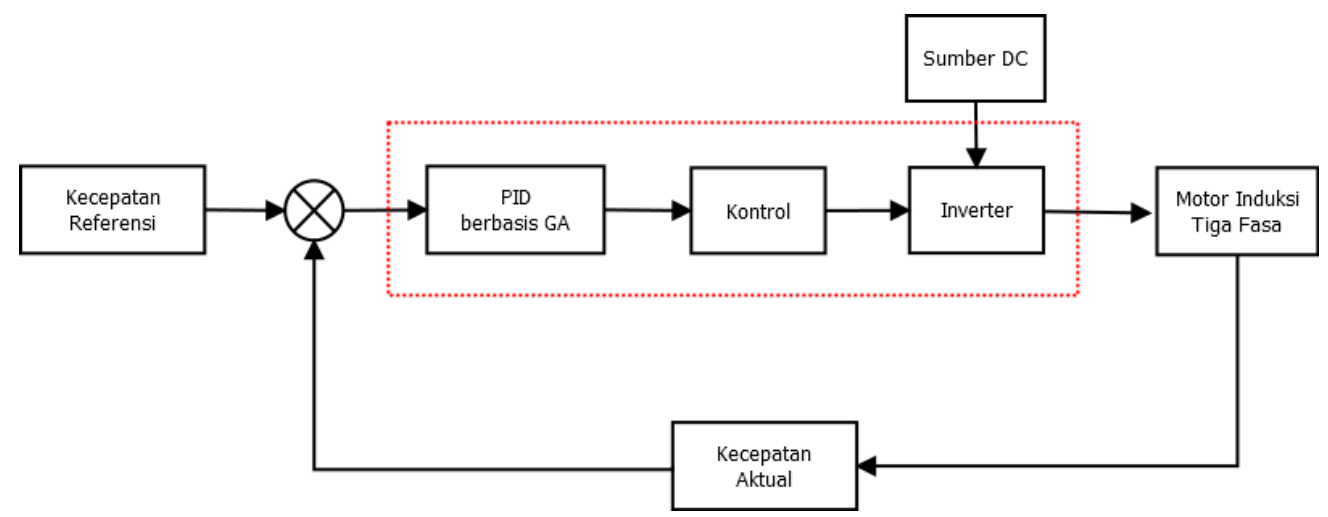

Gambar 1. Blok diagram inverter dan kontrol PID berbasis GA

\subsection{Pemodelan Motor Induksi Tiga Fasa}

Model motor induksi yang telah disediakan dalam SimPowerSystemsTM library seperti dalam Gambar 2. Motor induksi yang digunakan adalah jenis rotor sangkar tupai (squirrel cage). Untuk konfigurasi dan parameter yang digunakan seperti terlihat dalam Gambar 3.

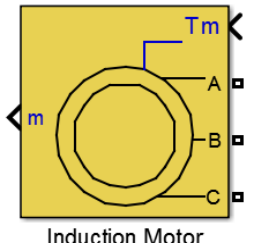

Induction Motor

$20 \mathrm{HP} / 460 \mathrm{~V} 1$

Gambar 2. Pemodelan motor induksi pada MATLAB Simulink

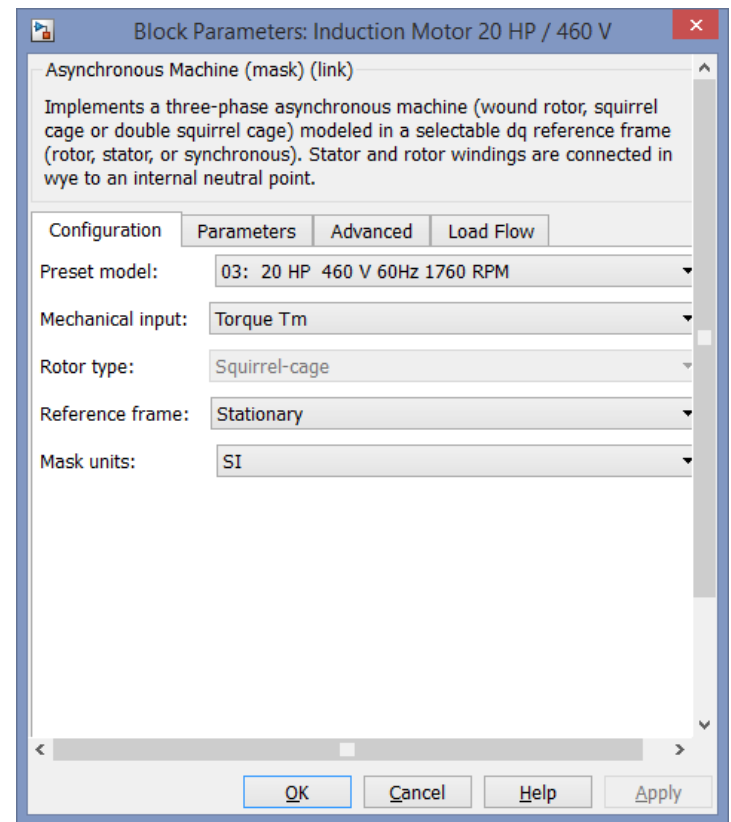

a. Blok konfigurasi motor induksi

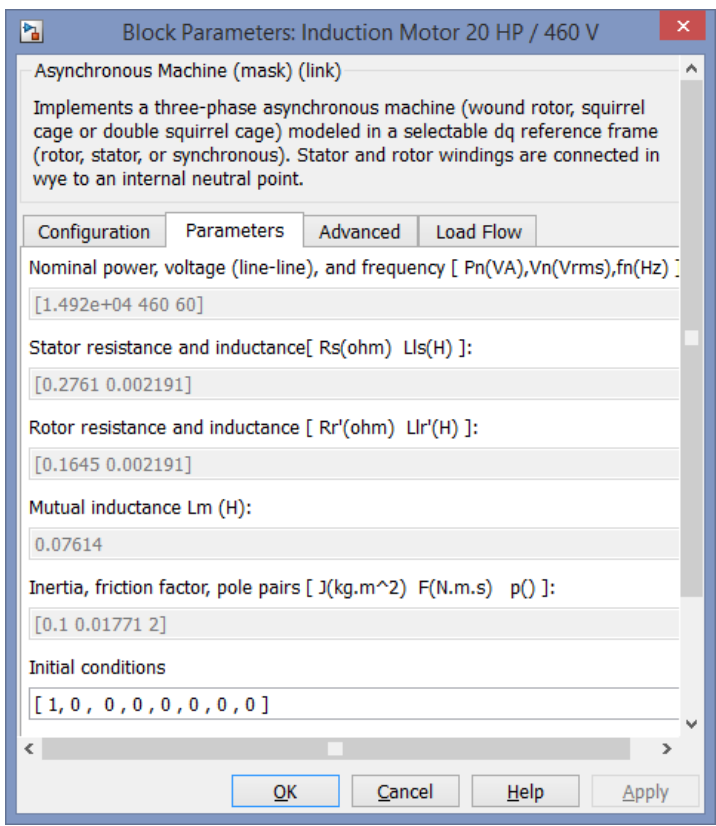

b. Blok parameter motor induksi Gambar 3. Blok konfigurasi dan parameter motor induksi pada MATLAB 


\subsection{Pemodelan Inverter}

Inverter merupakan rangkaian flip-flop yang melakukan pensaklaran secara bergantian terhadap listrik DC sehingga menghasilkan listrik AC. Inverter yang digunakan adalah inverter 3 fasa dengan komponen switching yaitu Insulated Gate Bipolar Transistor (IGBT) dengan nilai snubber resistance $(\mathrm{Rs})=1000 \mathrm{ohm}$, snubber capacitance $(\mathrm{Cs})=$ inf untuk mendapatkan snubber yang bersifat resistif, internal resistance devais yang dipilih (Ron) = 1e-3 ohm, dan forward voltage 0.8 volt. Gambar 4 menunjukkan inverter yang digunakan SimPowerSystemsTM library, untuk setting parameter inverter seperti telihat dalam Gambar 5.

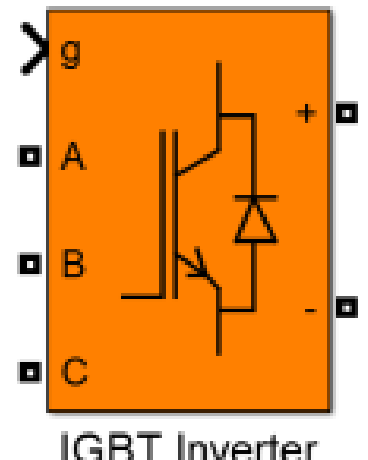

Gambar 4. Pemodelan inverter

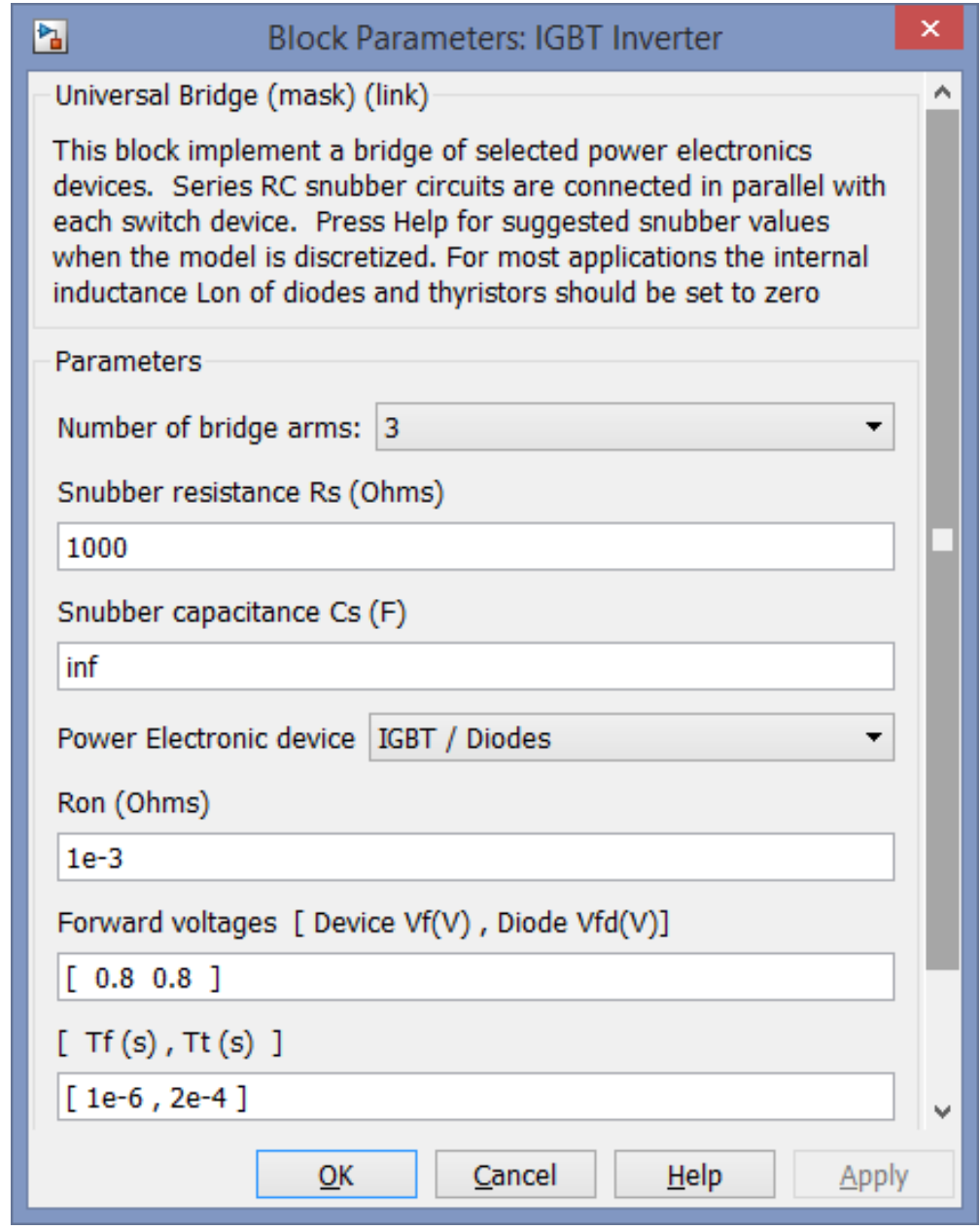

Gambar 5. Parameter inverter pada MATLAB 


\subsection{Pemodelan Vector Control}

Pada pemodelan vector control ini merupakan penghubung antara pengaturan vektor tegangan dengan PWM sebagai pengatur amplitudo dan frekuensi yang terdapat pada inverter. Hal ini berfungsi sebagai pengatur penyalaan IGBT yang ada pada inverter sehingga didapatkan frekuensi yang diinginkan untuk memutar motor induksi tiga fasa. Gambar 6 menunjukkan vector control yang digunakan di SimPowerSystemsTM library, untuk setting rangkaian vector control seperti telihat dalam Gambar 7 .

Vector Control

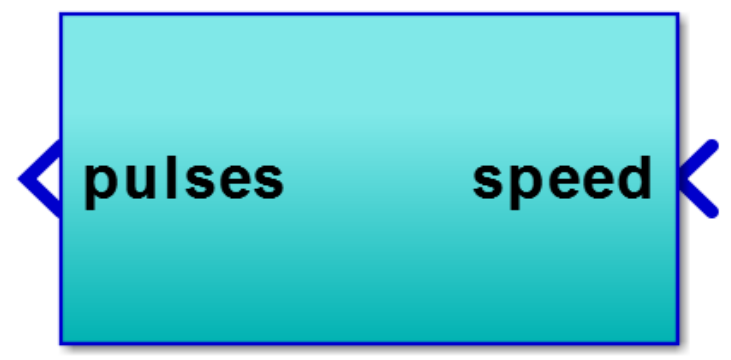

Gambar 6. Pemodelan vector control

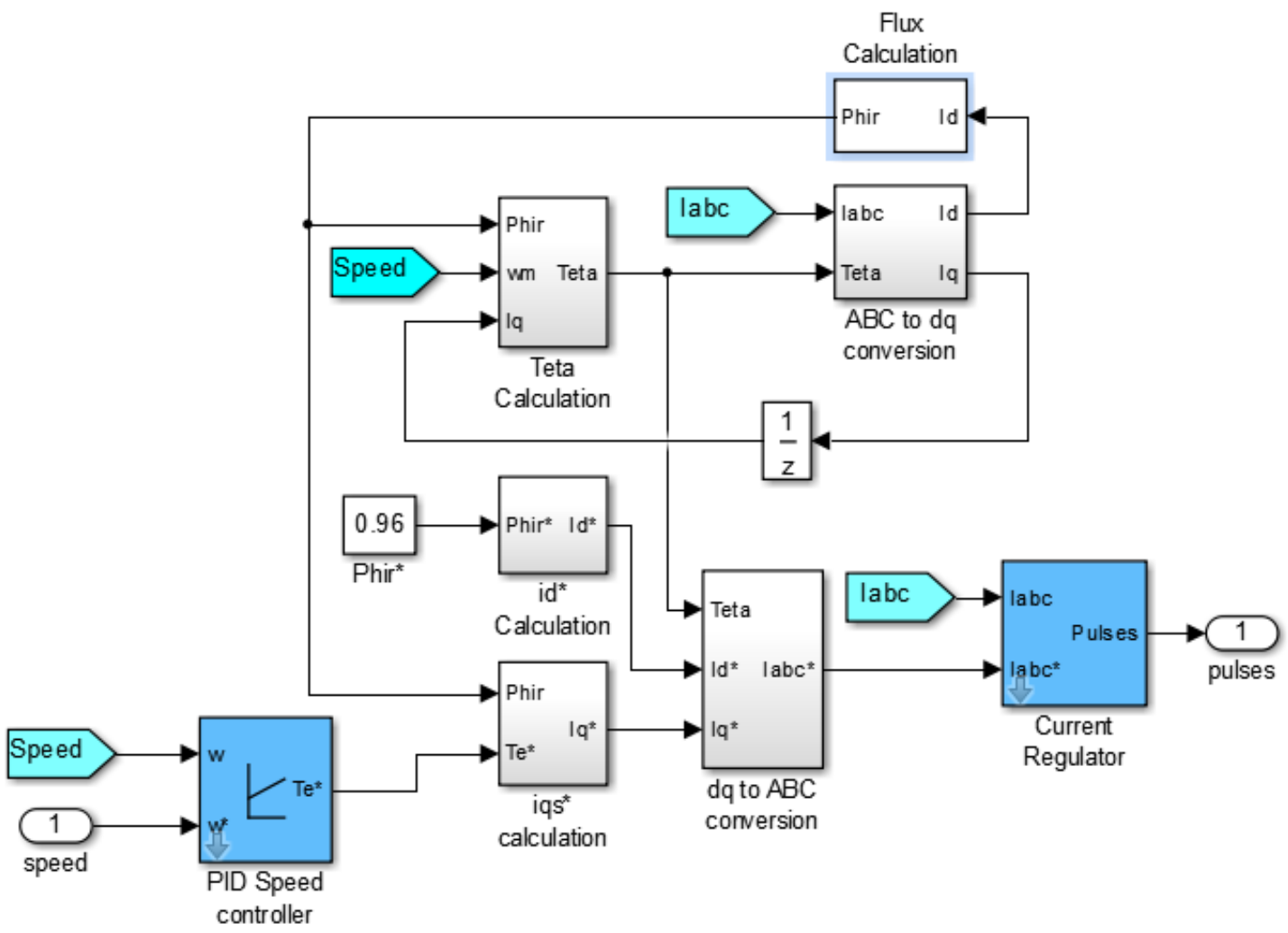

Gambar 7. Blok rangkaian transformasi vector control

\subsection{Kontroler PID}

Kontroler yang digunakan adalah PID. Kontroler berfungsi untuk menerima masukan dari sinyal kesalahan yang berasal dari selisih antara kecepatan referensi dan hasil kecepatan aktual motor saat ini. Untuk rangkaian yang digunakan pada SimPowerSystemsTM library dapat dilihat dalam Gambar 8. 


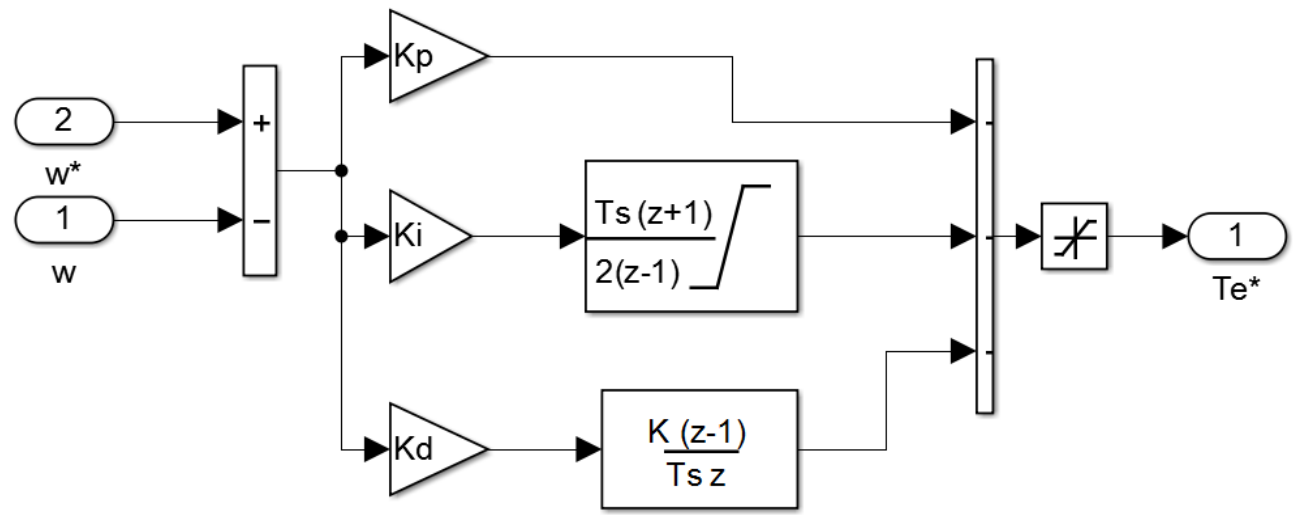

Gambar 8. Rangkaian kontroler PID pada MATLAB

\subsection{Penalaan GA}

Pada kontroler PID terdapat 3 parameter kontrol yang harus ditentukan yaitu $K p, K i$ dan $K d$. Oleh karena itu, kromosom $x$ dapat didefinisikan sebagai $x=\{K p, K i, K d\}$. Sebelum melakukan optimasi parameter kontrol, perlu dilakukan penentuan parameter input berupa parameter genetic algorithm yaitu jumlah populasi individu $(n)$, jumlah maksimum generasi, inisialisasi populasi dan penentuan parameter output berupa parameter kontroler PID $\{K p, K i$, $K d\}$.

Hal yang perlu diperhatikan pada penalaan GA juga parameter seleksi, crossover dan mutasi harus di atur sesuai dengan kebutuhan yang diinginkan sehingga didapatkan optimasi yang sesuai dengan respon kecepatan motor yang diharapkan.

\section{Hasil Penelitian dan Pembahasan}

Pada simulasi ini dilakukan untuk mengetahui perbandingan respon sistem kecepatan motor saat tanpa kontroler PID terhadap macam-macam nilai parameter kontroler PID yang diberikan pada setiap pengujian. Parameter kontroler berfungsi untuk mempertahankan kecepatan motor sesuai dengan kecepatan referensi yang mana pada simulasi ini kecepatan referensi di set $120 \mathrm{rad} / \mathrm{s}$. Time range yang digunakan pada setiap simulasi adalah $2 \mathrm{sec}$, dengan 4 beban bervariasi yang digunakan.

Dari hasil simulasi dapat dilihat nilai parameter kontroler PID berbasis GA dengan 4 variasi beban berbeda berdasarkan 5 pembatasan jangkauan nilai. Akan dipilih satu nilai parameter kontroler PID berdasarkan waktu naik $\left(t_{r}\right)$, waktu penetapan $\left(t_{s}\right)$ dan error steady state $\left(e_{s s}\right)$ terbaik.

Pada bagian pembahasan ini akan dijelaskan perbandingan hasil pengujian simulasi dengan lima jangkauan batasan nilai parameter $K p, K i$ dan $K d$ berdasarkan nilai $e_{s s}$ terbaik pada masing-masing beban yang digunakan. Berikut merupakan perbandingan kecepatan motor saat tanpa kontroler PID dan dengan kontroler PID berbasis GA :

\subsection{Perbandingan Saat Beban $0 \mathrm{Nm}$}

Hasil perbandingan respon kecepatan motor saat tanpa kontroler PID, saat menggunakan kontroler PID dengan nilai acak dan saat menggunakan kontroler PID berbasis GA pada beban $0 \mathrm{Nm}$ berdasarkan $e_{s s}$ terbaik dapat dilihat dalam Gambar 9. Sebagai acuan perbandingan $t_{r}$, $t_{s}$ dan $e_{s s}$ saat tanpa kontroler PID, PID dan kontroler PID berbasis GA dapat dilihat dalam Tabel 1. 


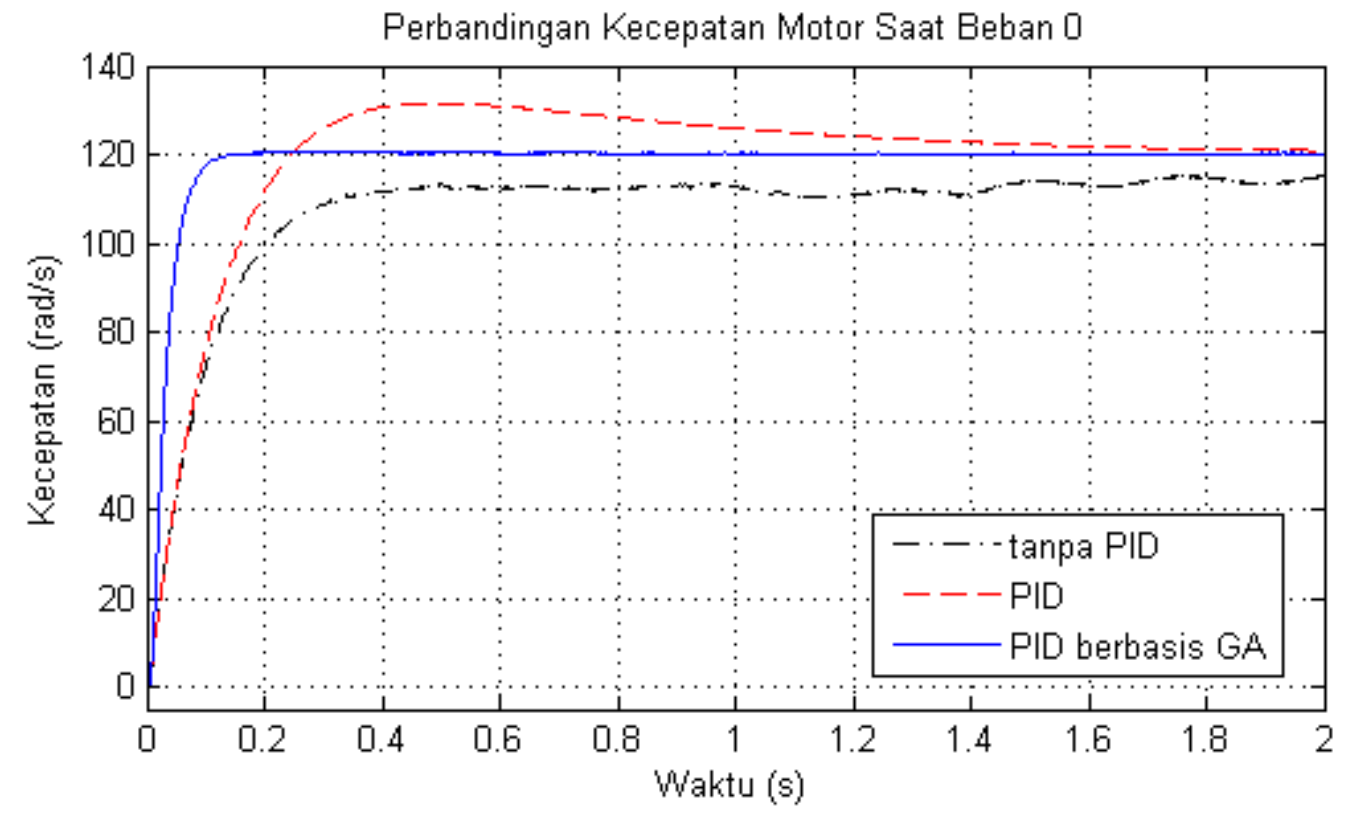

Gambar 9. Perbandingan respon kecepatan motor saat beban $0 \mathrm{Nm}$

Tabel 1. Perbandingan saat beban $0 \mathrm{Nm}$

\begin{tabular}{cccccccc}
\hline & $\mathbf{K p}$ & $\mathbf{K i}$ & $\mathbf{K d}$ & $\begin{array}{c}\mathbf{W m} \\
(\mathbf{r a d} / \mathbf{s})\end{array}$ & $\mathbf{t}_{\mathbf{r}}(\mathbf{s})$ & $\mathbf{t}_{\mathbf{s}}(\mathbf{s})$ & $\begin{array}{c}\mathbf{e}_{\mathbf{s s}} \\
(\%)\end{array}$ \\
\hline Tanpa PID & - & - & - & 115,1 & 0,22 & 1,65 & 4,08 \\
\hline PID & 20,0000 & 29,0000 & 2,0000 & 120,8 & 0,17 & 1,32 & 0,67 \\
\hline $\begin{array}{c}\text { PID berbasis } \\
\text { GA }\end{array}$ & 12,0651 & 1,3151 & 0,1874 & 120,1 & 0,15 & 0,18 & 0,08 \\
\hline
\end{tabular}

\subsection{Perbandingan Saat Beban $\mathbf{4 0} \mathrm{Nm}$}

Hasil perbandingan respon kecepatan motor saat tanpa kontroler PID, saat menggunakan kontroler PID dengan nilai acak dan saat menggunakan kontroler PID berbasis GA pada beban $40 \mathrm{Nm}$ berdasarkan $e_{s s}$ terbaik dapat dilihat dalam Gambar 10. Sebagai acuan perbandingan $t_{r}$, $t_{s}$ dan $e_{s s}$ saat tanpa kontroler PID, PID dan kontroler PID berbasis GA dapat dilihat dalam Tabel 2.

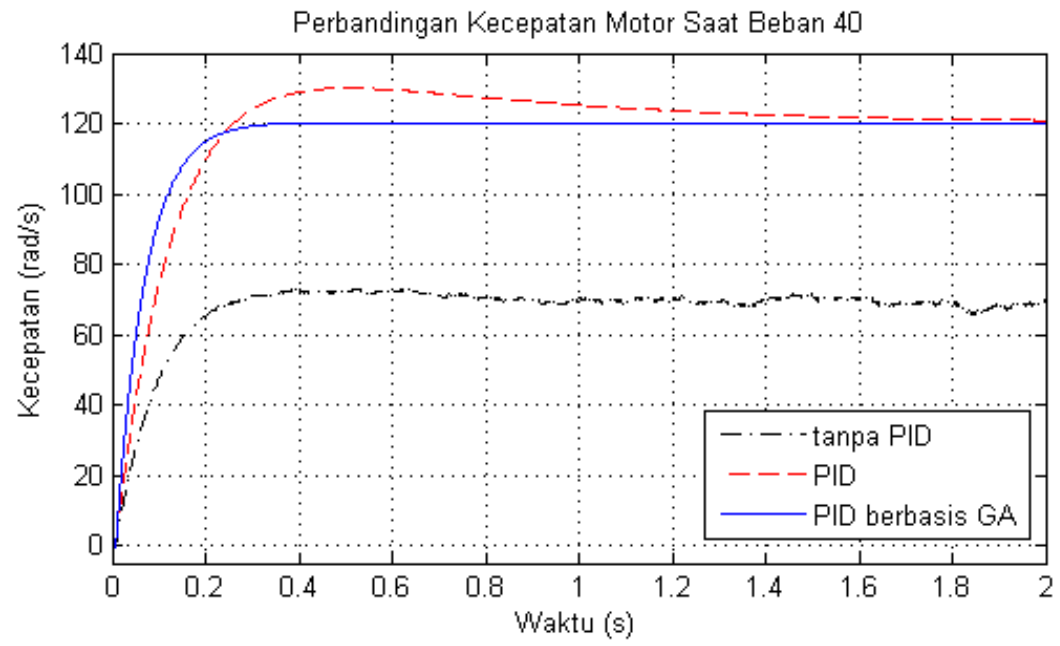

Gambar 10. Perbandingan respon kecepatan motor saat beban $40 \mathrm{Nm}$ 
Tabel 2. Perbandingan saat beban $40 \mathrm{Nm}$

\begin{tabular}{cccccccc}
\hline & $\mathbf{K p}$ & $\mathbf{K i}$ & $\mathbf{K d}$ & $\begin{array}{c}\mathbf{W m} \\
(\mathbf{r a d} / \mathbf{s})\end{array}$ & $\mathbf{t}_{\mathbf{r}}(\mathbf{s})$ & $\mathbf{t}_{\mathbf{s}}(\mathbf{s})$ & $\begin{array}{c}\mathbf{e}_{\mathbf{s s}} \\
(\%)\end{array}$ \\
\hline Tanpa PID & - & - & - & 69,6 & 0,16 & 2,00 & 42,02 \\
\hline PID & 20,0000 & 29,0000 & 2,0000 & 120,9 & 0,20 & 1,26 & 0,75 \\
\hline $\begin{array}{c}\text { PID berbasis } \\
\text { GA }\end{array}$ & 14,1574 & 5,9249 & 0,7715 & 199,9 & 0,14 & 0.24 & 0,08 \\
\hline
\end{tabular}

\subsection{Perbandingan Saat Beban $\mathbf{7 0} \mathbf{~ N m}$}

Hasil perbandingan respon kecepatan motor saat tanpa kontroler PID, saat menggunakan kontroler PID dengan nilai acak dan saat menggunakan kontroler PID berbasis GA pada beban $70 \mathrm{Nm}$ berdasarkan $e_{s s}$ terbaik dapat dilihat dalam Gambar 11. Sebagai acuan perbandingan $t_{r}$, $t_{s}$ dan $e_{s s}$ saat tanpa kontroler PID, PID dan kontroler PID berbasis GA dapat dilihat dalam Tabel 3.

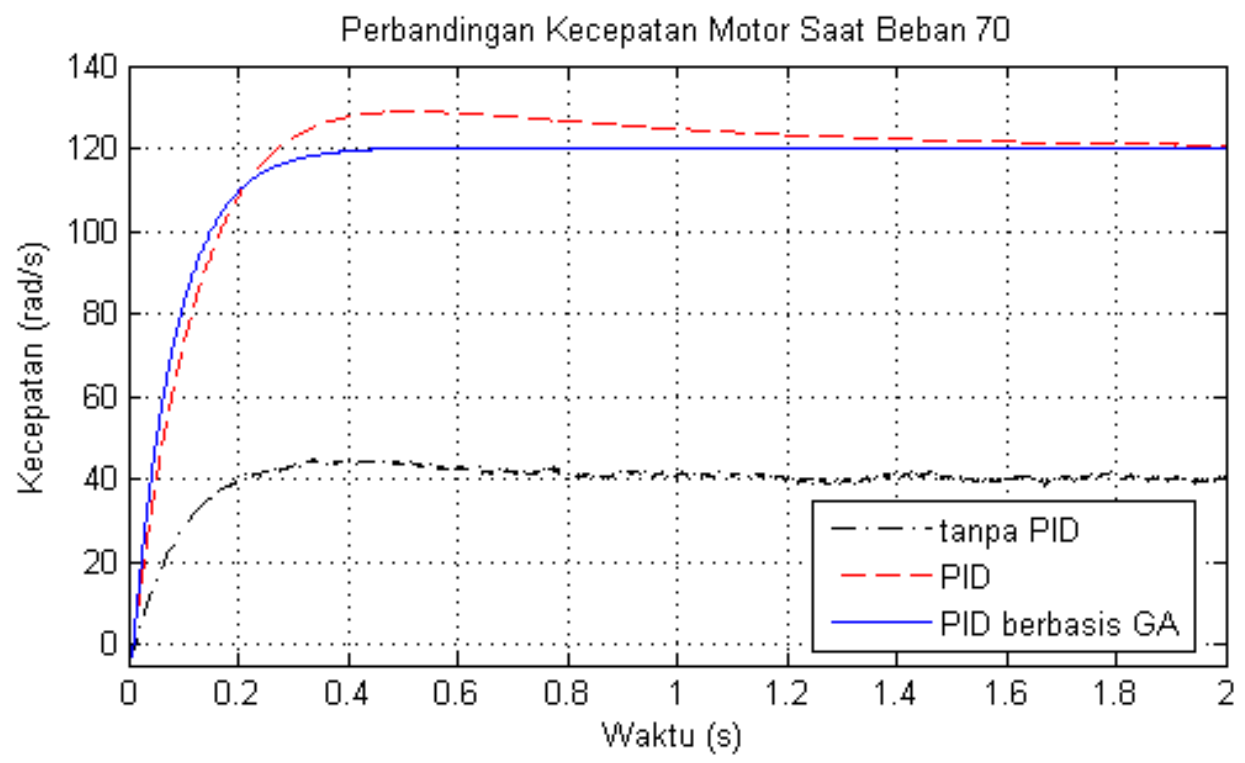

Gambar 11. Perbandingan respon kecepatan motor saat beban $70 \mathrm{Nm}$

Tabel 3. Perbandingan saat beban $70 \mathrm{Nm}$

\begin{tabular}{cccccccc}
\hline & $\mathbf{K p}$ & $\mathbf{K i}$ & $\mathbf{K d}$ & $\begin{array}{c}\mathbf{W m} \\
(\mathbf{r a d} / \mathbf{s})\end{array}$ & $\mathbf{t}_{\mathbf{r}}(\mathbf{s})$ & $\mathbf{t}_{\mathbf{s}}(\mathbf{s})$ & $\begin{array}{c}\mathbf{e}_{\mathbf{s s}} \\
(\%)\end{array}$ \\
\hline Tanpa PID & - & - & - & 40,6 & 0,14 & 2,00 & 66,16 \\
\hline PID & 20,0000 & 29,0000 & 2,0000 & 120,8 & 0,18 & 1,21 & 0,67 \\
\hline $\begin{array}{c}\text { PID berbasis } \\
\text { GA }\end{array}$ & 7,7826 & 7,3331 & 0,4742 & 120,1 & 0.17 & 0.32 & 0,08 \\
\hline
\end{tabular}

\subsection{Perbandingan Saat Beban $100 \mathrm{Nm}$}

Hasil perbandingan respon kecepatan motor saat tanpa kontroler PID, saat menggunakan kontroler PID dengan nilai acak dan saat menggunakan kontroler PID berbasis GA pada beban $100 \mathrm{Nm}$ berdasarkan $e_{s s}$ terbaik dapat dilihat dalam Gambar 12. Sebagai acuan perbandingan $t_{r}$, $t_{s}$ dan $e_{s s}$ saat tanpa kontroler PID, PID dan kontroler PID berbasis GA dapat dilihat dalam Tabel 4. 


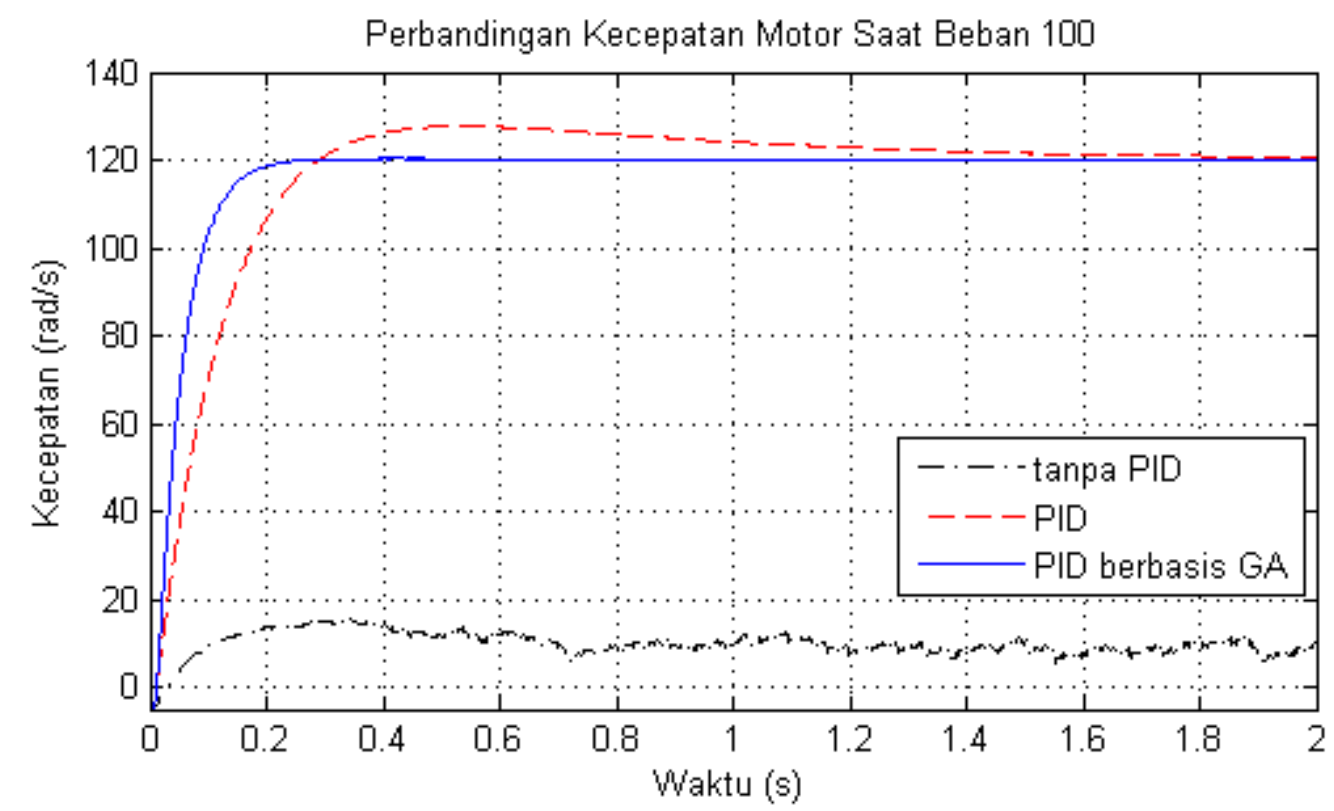

Gambar 12. Perbandingan respon kecepatan motor saat beban $100 \mathrm{Nm}$

Tabel 4. Perbandingan saat beban $100 \mathrm{Nm}$

\begin{tabular}{cccccccc} 
& $\mathbf{K p}$ & $\mathbf{K i}$ & $\mathbf{K d}$ & $\begin{array}{c}\mathbf{W m} \\
(\mathbf{r a d} / \mathbf{s})\end{array}$ & $\mathbf{t}_{\mathbf{r}}(\mathbf{s})$ & $\mathbf{t}_{\mathbf{s}}(\mathbf{s})$ & $\begin{array}{c}\mathbf{e}_{\mathbf{s s}} \\
(\%)\end{array}$ \\
\hline Tanpa PID & - & - & - & 10,3 & 0,06 & 2,00 & 91,38 \\
\hline PID & 20,0000 & 29,0000 & 2,0000 & 120,6 & 0,19 & 1,16 & 0,50 \\
\hline $\begin{array}{c}\text { PID berbasis } \\
\text { GA }\end{array}$ & 18,0111 & 16,2505 & 0,6706 & 120,1 & 0,27 & 0,61 & 0,083 \\
\hline
\end{tabular}

Dari hasil perbandingan kecepatan dengan 4 beban berbeda yang telah dilakukan dapat dilihat perbandingan perbedaan $e_{s s}$ pada masing-masing beban. Nilai $e_{s s}$ pada saat tanpa kontroler PID sangat besar dan kecepatannya tidak mencapai kecepatan referensi yang ditentukan, hal itu berlaku pada setiap beban yang diuji. Ketika digunakan kontroler PID nilai $e_{s S}$ lebih kecil dari pada ketika tanpa kontroler PID, tetapi kestabilan sistem masih lambat dan cenderung memiliki overshoot, hal tersebut dapat dilihat dari gambar perbandingan di setiap beban berbeda. Sedangkan saat digunakan kontroler PID berbasis GA respon kecepatan motor sangat baik, hal itu ditunjukkan dengan nilai $e_{s s}$ yang kecil pada setiap beban berbeda juga $t_{r}$ dan $t_{s}$ yang cepat. Hal tersebut dapat dilihat dari gambar perbandingan respon kecepatan motor saat tanpa kontroler, saat menggunakan kontroler PID dan saat menggunakan kontroler PID berbasis GA.

\section{Kesimpulan}

Berdasarkan hasil analisa dan pengujian sistem dapat disimpulkan sebagai berikut:

1. Berdasarkan pengujian sistem dengan 4 beban bervariasi yang telah dilakukan nilai $e_{s s}$ terbaik yaitu pada $0.083 \%$ pada masing-masing beban yang diberikan berdasarkan 5 jangkauan pembatasan nilai $K p, K i$ dan $K d$. Nilai tersebut berpengaruh pada waktu naik kecepatan motor dan waktu penetapan kecepatan motor. Dapat dilihat perbedaan antara kecepatan motor pada saat tanpa kontroler PID dengan 4 beban bervariasi tidak mencapai kecepatan referensi dan besarnya beban yang diberikan mempengaruhi kecepatan motor.

2. Nilai $K p$ berpengaruh mempercepat waktu naik yang dihasilkan dari respon kecepatan motor. Nilai Ki mempengaruh waktu penetapan yang dihasilkan oleh respon kecepatan

Sistem Pengaturan Kecepatan Motor Induksi Tiga Fasa Menggunakan Kontroler PID Berbasis Genetic Algorithm, Fatih Mutammimul Wildan; Ermanu Azizul Hakim; Diding Suhardi 
motor. Nilai $K d$ berperan untuk mengurangi nilai overshoot dari respon kecepatan motor. Beban yang diberikan mempengaruhi nilai parameter PID yang dihasilkan oleh optimalisasi menggunakan GA.

3. Penggunaan GA dalam pencarian parameter kontroler PID dapat memperbaiki respon kecepatan yang dihasilkan oleh motor berdasarkan waktu naik waktu penetapan dan nilai $e_{s s}$ dibandingkan respon sistem ketika tidak terkontrol.

\section{Referensi}

[1] Hamzah Berahim. 1994. PENGANTAR TEKNIK TENAGA LISTRIK Teori Ringkas dan Penyelesaian Soal. Yogyakarta: Andi Offset.

[2] Ismail Muchsin. 2009. Motor Induksi. Jurnal Pusat Pengembangan Bahan Ajar: UMB.

[3] Sumanto. 1993. MOTOR LISTRIK Arus Bolak - Balik Motor Sinkron Motor Induksi. Yogyakarta: Andi Offset.

[4] Yon Rijono. 2002. Dasar Teknik Tenaga Listrik Edisi Revisi. Yogyakarta: Andi.

[5] Zuhal. 1988. DASAR TEKNIK TENAGA DAN ELEKTRONIKA DAYA. Jakarta: Gramedia.

[6] Abu-Rub Haitham, lqbal Atif, Guzinski Jaroslaw. 2012. HIGH PERFORMANCE CONTROL OF AC DRIVES WITH MATLAB/SIMULINK MODELS. UK: John Wiley \& Sons, Inc.

[7] M Subchan Mauludin. 2011. Simulasi Kontrol PID Untuk Mengatur Putaran Motor AC. Semarang

[8] Nurhadi. Diktat Elektronika Daya. Malang: UMM.

[9] Rashid M.H. 2011. POWER ELECTRONICS HANDBOOK:devices, circuits, and applications handbook. USA: Butterworth-Heinemann.

[10] Aris Sugiharto. 2006. Pemrograman GUI dengan MATLAB. Yogyakarta: Andi Offset.

[11] Endra Pitowarno. 2006. ROBOTIKA DESAIN, KONTROL, DAN KECERDASAN BUATAN. Yogyakarta: Andi Offset.

[12] Ermanu Azizul Hakim, 2012. Sistem Kontrol. Malang: UMM Press.

[13] Muhamad Ali. 2010. Materi Kuliah Elektronika Daya. Yogyakarta: UNY

[14] Falahal Abadi, 2015, Desain Optimal Power System Stabilizer (PSS) PLTMH Berbasis Fuzzy PID Menggunakan Genetic Algorithm. Malang.

[15] Zainudin Zukhri. 2014. Algoritma Genetika Metoda Komputasi Evolusioner untuk Menyelesaikan Masalah Optimasi. Yogyakarta: Andi Offset.

[16] Muhammad Arhami dan Anita Desiani. 2005. Pemrograman MATLAB. Yogyakarta: Andi.

[17] The Mathworks, Inc., Le-Huy, H., 2016. Vector Control of AC Motor Drive. 